\title{
JÓLÉTI ÁLLAM: KORCSOPORTOK KÖZÖTTI ÚJRAELOSZTÁS?
}

\author{
Gál Róbert Iván ${ }^{1}$ - Medgyesi Márton² \\ ${ }^{1}$ NKI, TÁRKI, BCE \\ ${ }^{2}$ TÁRKI, MTA TK Szociológiai Intézet
}

\begin{abstract}
ÖSSZEFOGLALÓ
Tanulmányunkban azt az állítást kíséreljük meg új empirikus bizonyítékokkal alátámasztani, mely szerint a jóléti állam elsősorban életpályát finanszírozó intézmény; szegénységenyhítô, jövedelemkiegyenlítő szerepe másodlagos. Az állítás alátámasztása érdekében egy regresszió-elemzés segítségével elkülönítjük az anyagi helyzet szerinti különbségek és az életkor relatív jelentőségét a jóléti kiadások és bevételek eloszlásában. Eredményeink megerősítik a várakozásokat: akár a jóléti kiadásokhoz való hozzáférést, illetve e kiadásokhoz tett hozzájárulásokat leíró regressziós egyenletek együtthatóit, akár az általuk magyarázott szórásnégyzetet vizsgáljuk, az életkor számottevően fontosabbnak bizonyul, mint az anyagi helyzet. E megfigyelésnek számos következménye adódik a jóléti rendszer vizsgálata szempontjából, melyek közül e helyütt egy, politikatudományi szempontból is releváns elemet tárgyalunk: ha a jóléti rendszer valójában elsősorban életpályát finanszíroz korcsoportok közötti erőforrás-átcsoportosítás révén, akkor a közkiadások elöregedésére, a „gerontokráciára” vonatkozó állítások is más színben túnnek fel.
\end{abstract}

Kulcsszavak: jóléti támogatások célzása — intergenerációs transzferek • szegénység - jóléti állam • gerontokrácia

\section{BEVEZETÉS ${ }^{1}$}

Számos korábbi kutatás mutatta meg, hogy a magyar jóléti állam² nincs tekintettel a jövedelemkülönbségekre (Ferge, 2000; Ferge-Tausz, 2002; Révész, 2002; Benedek-Firle-Scharle, 2006; Szikra, 2014). Itt közölt eredményeink megerősítik e megfigyelést, de ki is egészítik azt, új kontextusba helyezve a jóléti rendszert. Az eddig ismertekkel összhangban mi is úgy találjuk, hogy a kapott juttatásoknak és támogatásoknak szinte semmi köze nincs az anyagi helyzethez. Ahhoz viszont, hogy a kedvezményezett hány éves, annál inkább. Ha megnézzük, kik állják a költségeket, az életkor ismét csak sokkal fontosabbnak bizonyul, mint a társadalmi-gazdasági státus. A szociálpolitikai intézmények sokkal inkább korosztályok, mintsem státuskategóriák között csoportosítják 
át a jövedelmeket. Fő kedvezményezettjei a gyermekek és idősek, finanszírozói pedig az aktív korúak, kiváltképp a jómódú aktívak.

A jóléti rendszer életpálya-finanszírozási megközelítése természetesen nem újdonság a társadalomtudományi szakirodalomban. A közgazdaságtanban Becker és Murphy (1988) már három évtizeddel ezelőtt életpálya-finanszírozó rendszerként írta a le a jóléti újraelosztást. De Boldrin és Montes (2005) vagy van Groezen, Leers és Meijdam (2003) is ebben a szellemben vizsgálja az oktatás és a nyugdijrendszer kapcsolatát; Folbre és Wolff (2012) pedig azt elemzi, hogy a jóléti állam intergenerációs jellegének figyelmen kívül hagyása milyen igazságossági és fenntarthatósági problémákat vet fel, és e problémákat milyen intézményi reformok tudnák kezelni.

Az életkori csoportok közötti újraelosztásra a társadalmi öregedés folyamatai is ráirányították a társadalomkutatók figyelmét. Ezek a kutatások sok esetben a jóléti rendszer gerontokráciájának veszélyére hívják fel a figyelmet, tehát arra, hogy a népesség korszerkezetének változásai miatt az idősek egyre inkább kisajátíthatják a jóléti programokat. A szóban forgó vélekedés három megfigyelésre épül: (1) a mai idős generációk több közkiadáshoz jutnak, mint a múltbéli idős generációk (Kotlikoff-Burns, 2012); (2) az idősebbek egy főre esően több közkiadáshoz jutnak, mint a gyermekek (Vanhuysse, 2013); és (3) az idős/gyermek közkiadási arány növekszik (Preston, 1984). Röviden, az idősek elveszik a fiatalabbak erőforrásait. A jelenséget a szakirodalom többféle névvel illeti: „szürke hatalom (grey power)” és „idősuralom (gerontocracy)” (Sinn-Uebelmesser, 2003); „idősekhez húzás (pro-elderly bias)” (Lynch, 2006; Tepe és Vanhuysse, 2010); egyes szerzők egyenesen „a generációk összecsapásáról (clash of generations)" írnak (Kotlikoff-Burns, 2012). Generációs konfliktusról akkor beszélünk, ha a vitatkozó felek a maguk álláspontját nyíltan korosztályi alapra helyezik (Szabó-Kiss 2013). Amennyiben a generációs érdekek képviselete a pártpolitikában is megjelenik, az jelentősen befolyásolhatja a jóléti rendszerek reformjának esélyeit (Bartha-Tóth, 2013).

Jelen tanulmányban nem azt vizsgáljuk, hogy melyik korcsoport részesedik nagyobb mértékben a jóléti állami programokból, hanem általában az életciklus mentén történő és az anyagi helyzet szerinti újraelosztás egymáshoz viszonyított fontosságát elemezzük. A tanulmány 2. szakaszában felrajzoljuk a magyar jóléti rendszer fontosabb kiadási fejezeteit és bevételi forrásait korcsoportos és anyagi helyzet szerinti bontásban. Először ábrákkal illusztráljuk, hogy a magyar jóléti rendszer a kifizetési oldalon gyakorlatilag kizárólag az életpályájuk inaktív szakaszában lévőket, a gyermekeket és az időseket finanszírozza, adózási oldalról nézve zömmel az aktív korukban lévők befizetéseiből. A hozzáférésben gyakorlatilag semmilyen szerepet nem játszik a háztartások anyagi helyzete. Az adóbefizetésekben mutatkozik különbség anyagi helyzet szerint, de itt is az életpályán aktuálisan elfoglalt hely a fontosabb. A 3. szakaszban bemutatunk egy többváltozós regresszió-elemzésre épülő 
eljárást, melynek segítségével elkülönítjük az anyagi helyzet és a korcsoporthoz tartozás relatív jelentőségét a jóléti kiadások és bevételek eloszlásában. A módszer segítségével igazoljuk, hogy a szociálpolitika azon leírása, mely szerint a jóléti állam nemzedékek közötti erőforrás-átcsoportosítás révén életpályát finanszírozó intézmény, nagyobb összhangban van a megfigyelt valósággal, mint a szegénységenyhítő, jövedelemkiegyenlítő jóléti államé. Végül a 4. szakaszban eredményeink egy, a jóléti rendszer politikai gazdaságtanával foglalkozó viták szempontjából releváns következményével foglalkozunk.

\section{A JÓLÉTI PROGRAMOK ÉLETKOR ÉS ANYAGI HELYZET SZERINT}

Első megközelítésben ábrákon vizsgáljuk a jóléti kiadások és az ezeket fedező adók és járulékok korszerkezetét a háztartások anyagi helyzete szerint képzett csoportokban. Módszertani megjegyzésekkel kezdjük a következő szakaszban. Ismertetjük az egyes kategóriák definícióit; az adatok forrásait; a figyelembe vett juttatásokat és támogatásokat, illetve adókat és járulékokat; valamint a korcsoport és anyagi helyzet szerinti profilok kiszámítása során alkalmazott feltevéseket. E szakaszban, ahol az ábrák csupán illusztrációs célokat szolgálnak, 10 korcsoportot és öt anyagi helyzet szerinti csoportot különböztetünk meg. A rákövetkező alfejezetben bemutatjuk az eloszlásokat.

A közkeletú szóhasználatot követve, a bevételeket és kiadásokat az állam oldaláról nézzük, tehát a bevétel a háztartások számára adó- és járulékfizetés, a kiadás pedig készpénzes támogatás vagy természetbeni juttatás. ${ }^{3}$

\section{Módszertani megjegyzések}

Az állami jóléti kiadások korprofiljainak vizsgálatánál a KSH Háztartási Költségvetési Felvételének (HKF) 2012. évi adatait használjuk, amelyek a 2011-es év jövedelmeiről és fogyasztásáról tartalmaz adatokat. A készpénzes támogatásokat a HKF részletesen rögzíti a háztartási jövedelmek felmérése során. Elemzésünkben figyelembe vettük a HKF által felmért összes készpénzes ellátást, melyek a következők: öregségi nyugdíj, nyugdij-kiegészítés, árvaellátás, időskori járadék, táppénz, munkanélküli járadék, munkanélküliek jövedelempótló támogatása, anyasági támogatás, TGYÁS, GYED, GYES, GYET, családi pótlék, rendszeres segély, nem rendszeres segély, lakásfenntartási támogatás, gyermekvédelmi támogatás, ápolási díj, ösztöndíj. ${ }^{4}$ Az egyének által kapott készpénzes ellátások mintából becsült értékeit az Eurostat költségvetési kiadásokkal kapcsolatos adatbázisában (gov_10a_exp) szereplő összes kiadás értékeihez igazítottuk. 
Ahhoz, hogy a jóléti állam által nyújtott támogatásokat a háztartások tagjai között felosszuk, néhány esetben feltevésekkel kell élnünk. Erre egyrészt azért van szükség, mert az adatbázis nem egyéni, hanem háztartási szinten rögzít bizonyos támogatásokat, tehát nem világos, hogy a háztartás mely tagjai részesültek benne, másrészt elvi kérdések is felmerülhetnek a támogatások incidenciájával kapcsolatban. Nevezetesen, nem magától értetődő, hogy a családtámogatásokat a szülő vagy a gyermek kapja-e. A kérdés eldöntéséhez egy kétkérdéses tesztet alkalmaztunk: támogatna-e a társadalom (i) egy gyermeket, akinek nincsenek szülei, (ii) egy gyermektelen párt. A válasz igen az első, és nem a második kérdésre. Ennek alapján a családtámogatásokat a gyermekeknél írtuk jóvá, pontosabban a háztartásban élő 18 év alatti gyermekeknél, több gyermek esetén egyenlően elosztva. ${ }^{5}$

Az igénybe vett természetbeni ellátások értékét a HKF nem rögzíti. Ez esetben az ellátási értéket (és néhány esetben magát az igénybevételt) kiegészítő információk felhasználásával becsültük a szakirodalomban leggyakrabban alkalmazott hipotézis felhasználásával, miszerint a fogyasztó számára az ellátás értéke megegyezik a szolgáltatás előállításának átlagköltségével (Verbist-FörsterVaalavuo, 2012). Természetesen tudatában vagyunk, hogy ez csupán feltételezés, ami nem veszi figyelembe a szolgáltatások minőségi eltéréseit.

A közoktatás esetében a legegyszerübb a helyzet, mert az igénybe vevőket be tudjuk azonosítani a HKF alapján. Minden háztartástagról tudjuk, hogy a felvétel idején járt-e óvodába, tanult-e nappali tagozaton, és ha igen, milyen iskolai fokozatban. Az általános, közép- és felsőoktatás esetében a megfelelő típusú oktatásban résztvevőkhöz imputáltuk az adott iskolai fokozatra fordított közkiadás egy főre eső értékét.

Az egészségügyi kiadások esetében szintén a szakirodalom által gyakran alkalmazott módszertan szerint jártunk el. Ez a módszer (Verbist et al., 2012) az egészségügyi kiadásokat nem az azokat tényleg igénybe vevők között osztja fel, hanem figyelembe veszi, hogy az egészségügy azok számára is értékes, akik az adott évben nem vettek igénybe ilyen szolgáltatásokat, hiszen számukra is védelmet nyújt a rendszer a megbetegedés kockázata ellen. Ezért az egészségügyi szolgáltatásokra fordított állami kiadásokat egyenlően osztottuk el, figyelembe véve az egészségügyi szolgáltatások igénybevételében nem, korcsoport és iskolai végzettség szerint megfigyelhető különbségeket („insurance value approach"). Az egészségügyi rendszer igénybevételének nem, életkor és iskolázottság szerinti különbségeiről az Európai Lakossági Egészség Felmérés (ELEF) 1. hullámának adataiból szereztünk információt.

A jóléti rendszer bevételeinek eloszlását ugyancsak a HKF alapján vizsgáltuk. A munkát terhelő adók (szja, tb-járulékok) esetében a bruttó és nettó háztartási jövedelem különbségeként számítjuk a háztartás által fizetett direkt adókat, és ezt a munkajövedelem arányában osztjuk fel a háztartástagok között. A HKF a háztartásijövedelem-vizsgálatokkal szemben a háztartási fo- 
gyasztásról is részletes adatokat közöl, így az áfa-befizetések eloszlásának vizsgálatára is alkalmas. Az áfa esetében a HKF-ben háztartási szinten számított forgalmi adót az OECD II-es ekvivalencia-skála segítségével bontottuk fel egyéni adófizetésre. A jóléti rendszer bevételeire vonatkozó incidenciafeltevésünk, hogy a gyermek fogyasztását terhelő adót maguk a gyermekek fizetik.

A fizetett jövedéki adó kiszámításához a benzin-, az alkohol- és a cigarettafogyasztás jellemzőit kellett figyelembe venni. A jövedéki adó benzinre jutó részét a HKF-ben rögzített üzemanyag-fogyasztási információ alapján számítottuk. ${ }^{6}$ Az egyéni cigaretta- és alkoholfogyasztást azonban a HKF nem rögzíti, ezért a háztartások által szeszes italra, illetve dohánytermék-fogyasztásra fordított kiadást az ELEF-ben megfigyelhető nem és életkor szerinti eltérések alapján osztottuk fel a háztartástagok között. Az üzemanyagból, alkoholtermékekből, illetve dohánytermékekből befolyó jövedékiadó-bevételek egymáshoz viszonyított arányát ismerve és az előbb kiszámított kormegoszlásokat ezekkel az arányokkal súlyozva kaptuk meg a jövedékiadó-befizetés életkori és anyagi helyzet szerinti arányait.

Az így kiszámított egyéni adóbefizetést felszoroztuk oly módon, hogy az egyes adófajták összege kiadja az Eurostat költségvetési bevételekre vonatkozó adatbázisában (National Tax Lists) szereplő értékeket. A jóléti programok finanszírozásának összesítésénél és a nettó adó számításánál abból a feltételezésből indultunk ki, hogy a bevételek és kiadások összege megegyezik. Amit nem fedeznek a célzottan, jóléti célra beszedett tb-járulékok, azt a költségvetés általános adókból fedezi. Az általános adók összetétele: 48\% szja, 52\% indirekt adó.

A háztartások tagjainak anyagi helyzetét nem a rendelkezésre álló jövedelemmel mérjük, mert az tartalmazza azokat a jóléti transzfereket is amelyeknek az eloszlását vizsgáljuk. Ehelyett olyan társadalmi-gazdasági státusz változót képeztünk, amely a háztartástagok iskolázottságát, foglalkozási presztízsét, valamint az anyagi életszínvonalra vonatkozó információkat kombinálja. Az iskolázottságot a nappali tagozatos iskolai képzésben töltött évek számával mértük. Az eredeti HKF-változót, amely a legmagasabb iskolai végzettséget méri, az OECD (2013) A1.1. táblázata alapján konvertáltuk évekre. Mivel itt háztartási szintû anyagi helyzet változót kívántunk képezni, a háztartás legmagasabb iskolai végzettségư felnőttjének az iskolában töltött éveivel számoltunk. Ami a foglalkozást illeti, a HKF a tényleges foglalkozást (ISCO-88) rögzíti az aktuális fó munkahelyen (az aktív korúaknál) vagy az utolsó munkahelyen (az inaktívaknál). Ezeket a kódokat a Ganzeboom és Treiman (2010) által kifejlesztett módszerrel nemzetközi társadalmi-gazdasági foglalkozási státusz index (ISEI) értékké alakítottuk át. A háztartási szinten vett foglalkozási presztízs a legmagasabb pontszámmal rendelkező felnőtt háztartás tagjának értéke.

Az anyagi életszínvonalra vonatkozó mérésünk a HKF kilenc olyan változóján alapul, amely a háztartás pénzügyi nehézségeit, illetve a tartós fogyasz- 
tási cikkekkel való ellátottságát értékeli. A következő változókat vettük figyelembe. Képes-e a háztartás: váratlan kiadások fedezésére; a lakóhely megfelelő fütésére; egyhetes nyaralás finanszírozására; arra, hogy hús, csirke vagy hal kerüljön az asztalra minden második napon. Előfordult-e, hogy nem fizették be a hitel törlesztőrészletét, bérleti díjat, közüzemi számlát. Továbbá van-e mosógépük, színes televíziójuk, telefonjuk vagy autójuk. Ezek a változók ugyanazok, mint amelyeket az Eurostat használ a súlyos anyagi depriváltság mutatók megalkotásához (lásd Guio, 2009). Itt azonban nem szegénység-indikátort, hanem anyagi életszínvonal indikátort képezünk belőlük. A háztartások anyagi helyzetét mérő változót az iskolázottság, a foglalkozási presztízs és az anyagi életszínvonal változóiból főkomponens-elemzés segítségével alakítottuk ki.

Jóléti kiadások és bevételek korcsoport és anyagi helyzet szerint

A következő ábrákon a vízszintes tengelyen mutatjuk a korcsoportokat, a függőleges tengelyen pedig a bevételek, illetve a kiadások egy före eső összegeit. Az anyagi helyzet szerinti ötödökbe a korábban tárgyalt anyagi státus változó alapján soroljuk az egyéneket. Mivel az ábrák csak illusztrációs célt szolgálnak, nem törekszünk arra, hogy a bevételekre és kiadásokra azonos skálát használjunk.

Kiadási oldalon a természetben nyújtott közszolgáltatások közül mind az oktatási, mind az egészségügyi ráfordításokat fel tudjuk bontani korcsoportok és az anyagi helyzet kategóriái szerint. Esetszám-korlátok miatt a készpénzes programokat egy kategóriában tárgyaljuk. A várakozásnak megfelelően az oktatási közkiadások szinte kizárólag életkor szerint szóródnak (lásd az 1. ábra Oktatás paneljét). A magasabb beiskolázási hányad miatt a legfelső ötödben valamivel magasabb az érték már a 11-20 éves korcsoportban is, de főképpen a 21-26 évesek között jelentős az anyagi helyzet szerinti eltérés, és a legfelső ötödben mutatkozik valamennyi kiadás 26 éves kor felett is. A fő különbség azonban életkori: majdnem a teljes kiadás az első három korcsoportra koncentrálódik, a többi hét korcsoport szinte semmit nem kap.

Az egészségügyi ráfordítások ábrája (1. ábra, Egészségügy panel) ugyancsak az életkor dominanciájára utal az anyagi helyzettel szemben, de az összefüggések bonyolultabbak. A kirajzolódó kép szerint a kisgyermekek, közülük is elsősorban az újszülöttek, csak ez a korcsoportos felbontásban nem látszik, valamivel több egészségügyi ellátást kapnak, mint az iskoláskorúak. A 20-as éveik végén, a 30-as éveik elején járók között, valószínúleg a szülésekkel öszszefüggésben, emelkednek a kiadások minden státuskategóriában, de különösen a rosszabb anyagi helyzetúek körében. A valódi növekedés azonban csak az 50 évet már betöltöttek körében kezdődik, minél rosszabb anyagi helyzetú valaki, annál fiatalabb korban. Ez nem pusztán a jövedelem és az egész- 
ségi állapot kapcsolatának köszönhető, hanem a jövedelem és a halálozás közötti összefüggésnek is. Közismert, hogy az egészségi ráfordítások kiugróan nagy részét a halál beállta előtti hónapokban költik el. Mivel a kis jövedelmúek korábban halnak meg, e jövedelemkategória tagjai már viszonylag alacsonyabb életkorban több egészségi ráfordítást kapnak.

Az 1. ábra Készpénzes programok panelje, mint ezt az előző szakaszban már részleteztük, a családtámogatásokat, a táppénzt, a munkanélküli ellátásokat, az önkormányzati és a központi kormány által folyósított segélyeket, valamint a nyugdijakat tartalmazza. Az ábra kisebb eltérést mutat anyagi helyzet szerint, de annál erősebb életkori hatásról tanúskodik. Az aktív korúak körében a rosszabb anyagi helyzetúek kapnak több transzfert, az idősek között pedig a jobb anyagi helyzetúek. Ez a szóródás azonban eltörpül az életkor szerinti különbségek mellett: a 60 év felettiek átlagosan több mint ötször annyi készpénz-transzfert kapnak, mint az aktív korúak.

Tekintve, hogy a magyar szociálpolitikai rendszerben a készpénzes programok meghatározó jelentőségűek, nem meglepő, hogy az összes jóléti ráfordítás profilja (3. ábra, Kiadások összesen panel) ugyancsak életkor-dominanciát mutat. A görbék anyagi helyzettől függetlenül egyöntetúen emelkednek gyermekkorban, csökkennek az aktív korúaknál, és jelentősen emelkednek ismét az idősek körében. Ezt az általános képet csak kisebb mértékben színezik az anyagi helyzet szerint megfigyelhető különbségek, amelyek az aktív korúak körében a rosszabb anyagi helyzetűek, míg az idősek körében a jobb anyagi helyzetúek előnyét mutatják.

Ami a bevételi oldalt illeti, a 2. ábra két panelje (Direkt adók és Indirekt adók) az életkori hatások mellett lényegesen erősebb jövedelmi hatásokat mutat, mint a kiadási oldal eloszlásai. A szorosan a legális munkavállaláshoz kötődő direkt adók (tb-járulék és személyi jövedelemadó) korprofilja meredekebben emelkedik az iskoláikat befejezők körében, és meredekebben csökken a nyugdíjba vonuló korosztályokban, mint az indirekt adóké. Mindenesetre az adófizetés túlnyomó része az aktív életkorúakra korlátozódik (lásd a 3. ábrán a Bevételek panelt). Ebből a szempontból a bevételi oldal nem különbözik a kiadási oldaltól. Míg azonban a kiadások esetén az anyagi helyzetnek csak egy-két esetben volt érzékelhető szerepe, a bevételek nemcsak életkor, hanem anyagi helyzet szerint is szóródnak. A legfelső kvintilisben lényegesen több a számottevő adót fizető korcsoport, mint a legrosszabb anyagi helyzetűek között és a legtöbb korcsoport esetében az egy főre eső értékek is jócskán magasabbak a jómódúak, mint a szegények körében. 
1. ábra. Állami jóléti kiadások korprofiljai egyes anyagi helyzet szerinti kvintilisekben, 2011-ben (éves egy főre jutó értékek, ezer Ft)

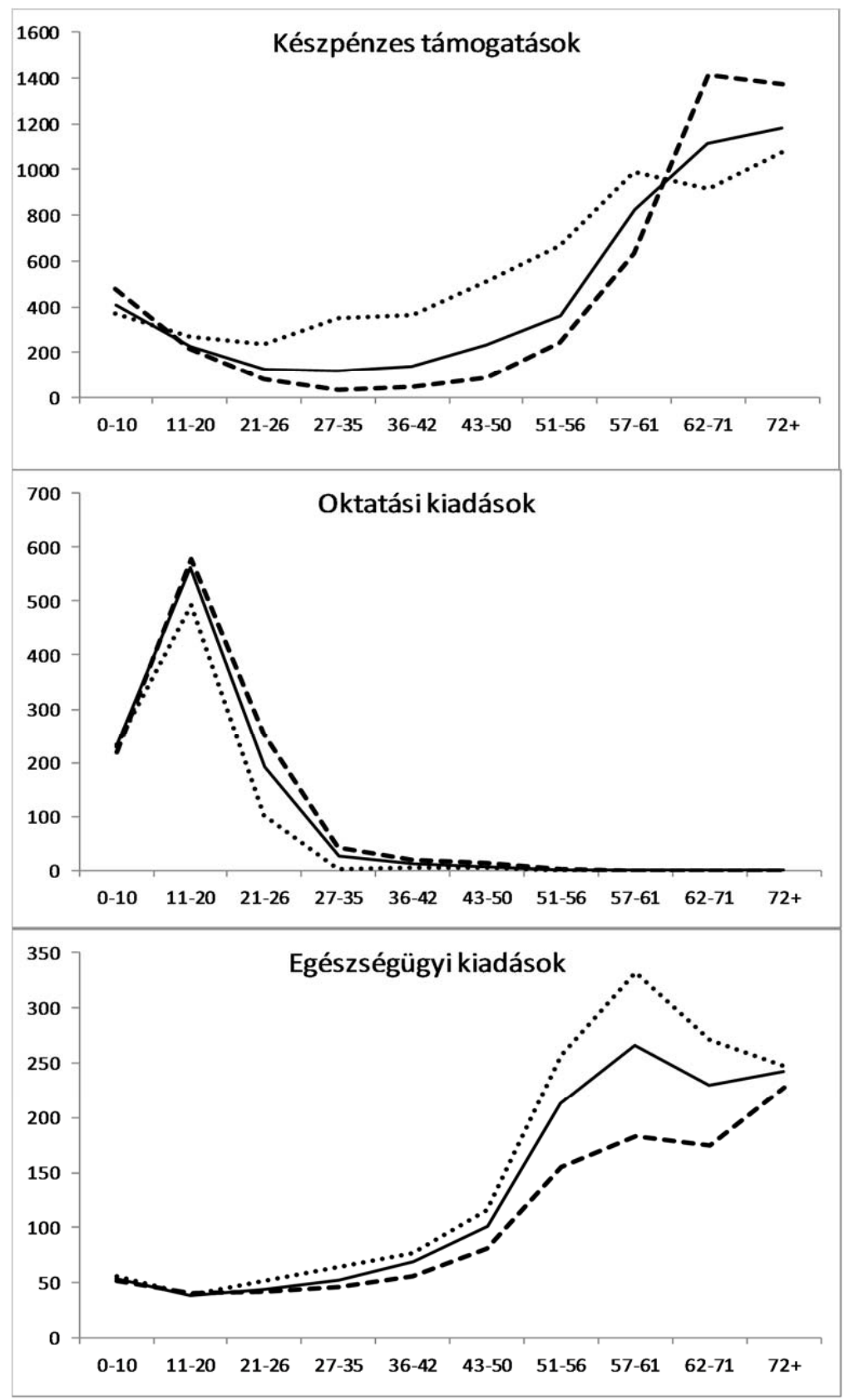

•.... Legrosszabb anyagi helyzet Összesen 
2. ábra. Állami jóléti bevételek korprofiljai egyes anyagi helyzet szerinti kvintilisekben, 2011-ben (éves egy före jutó értékek, ezer Ft)

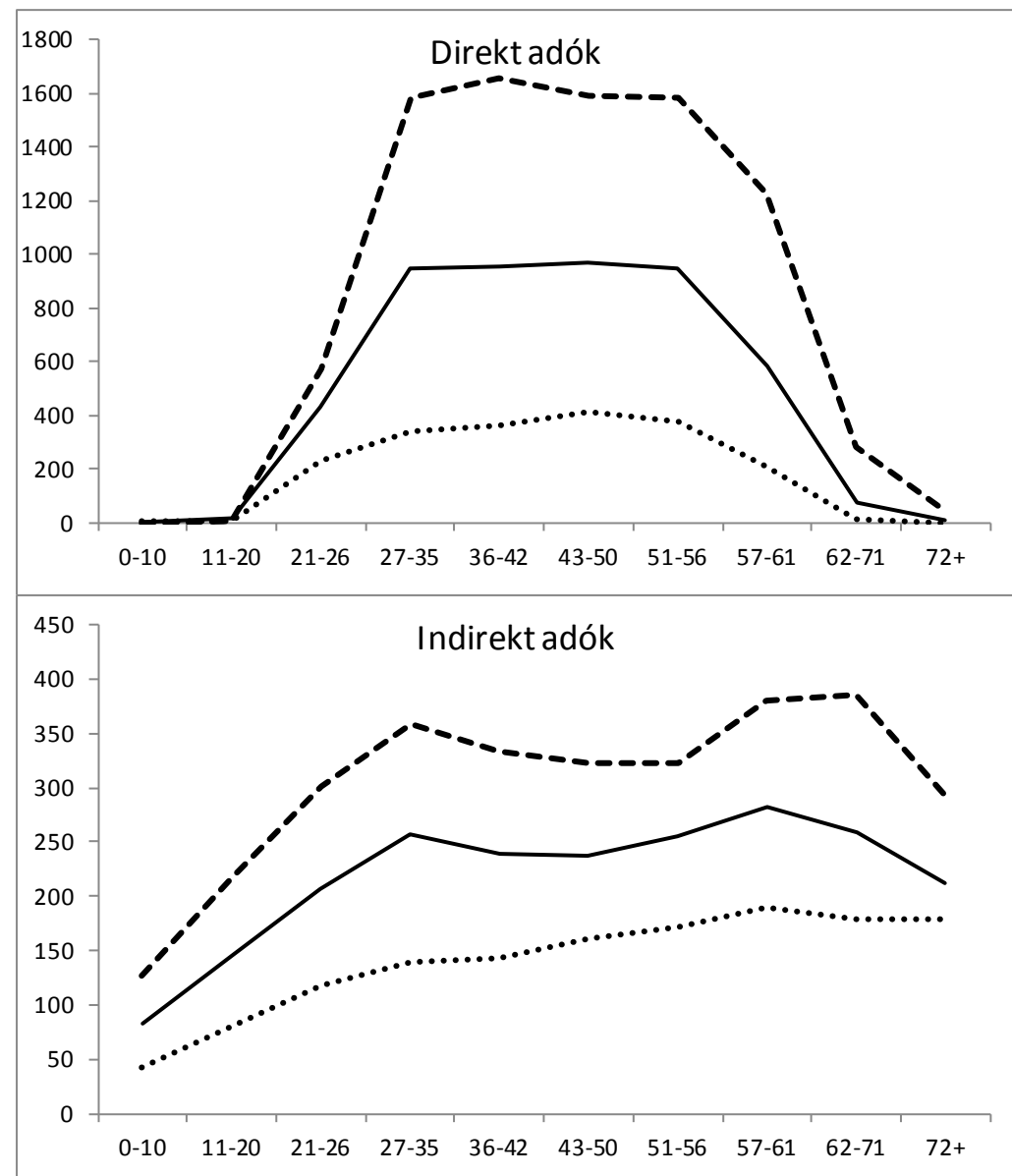

..... Legrosszabb anyagi helyzet - - - - Legjobb anyagi helyzet ——összesen

Forrás: A szerzők számítása 
3. ábra. Az összesített állami jóléti kiadások, bevételek és a nettó kiadások korprofiljai egyes anyagi helyzet szerinti kvintilisekben, 2011-ben (éves egy főre jutó értékek, ezer Ft)
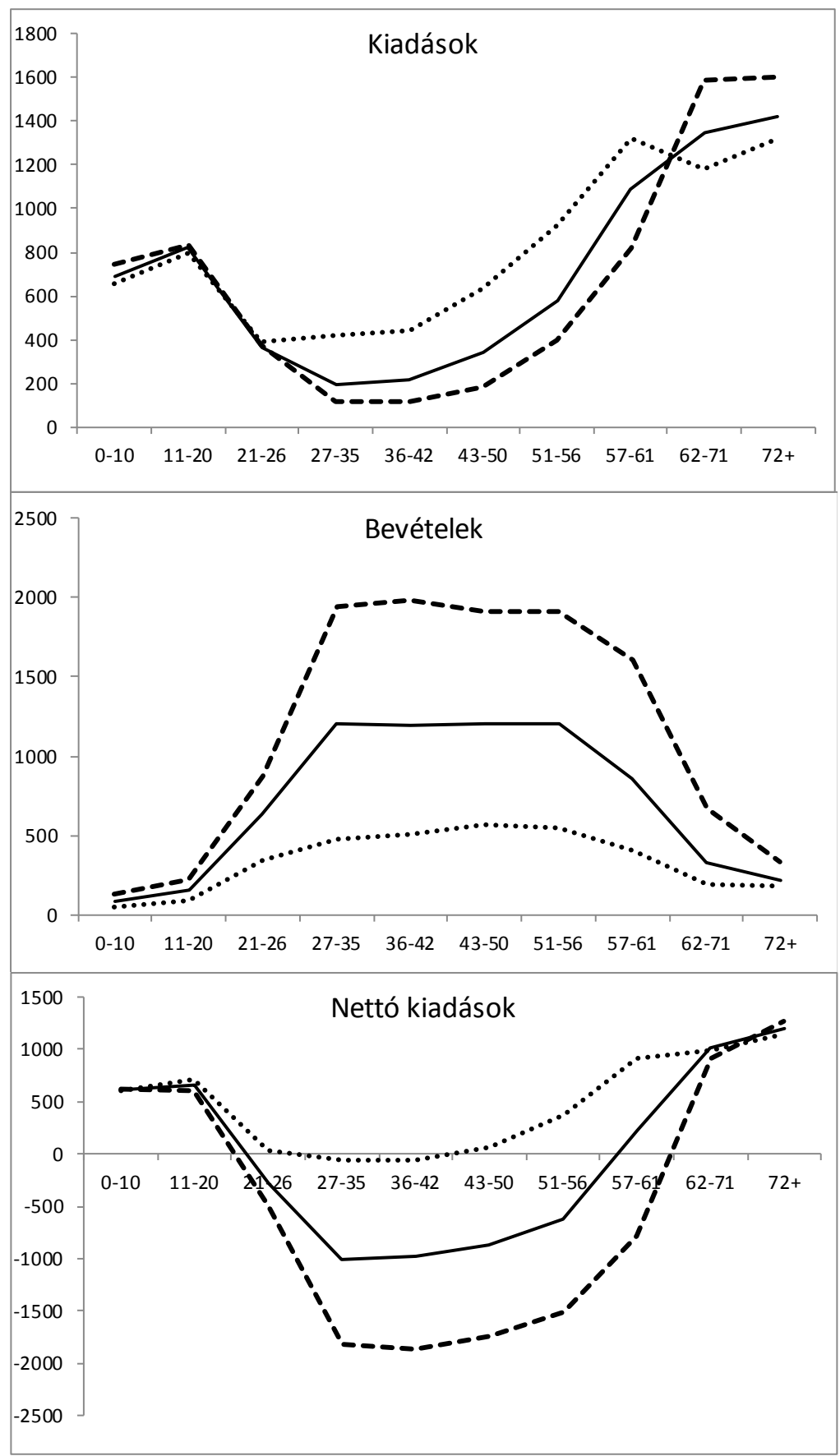

...... Legrosszabb anyagi helyzet ---- Legjobb anyagi helyzet Összesen 
Vizuális vizsgálataink eredményét a 3. ábra Nettó kiadások paneljében foglaljuk össze. A következő megállapításokat tesszük (a részletes számokat a Függelék F1. táblázatában közöljük):

1. 20 éves kor alatt és 56 éves kor felett egyik anyagi helyzet szerinti ötödben sincs olyan korcsoport, amely nettó adófizető lenne.

2. Összességében a 27-35 éves korosztály a legnagyobb nettó adóbefizető, de anyagi helyzet szerint megbontva változatos a kép. A két legrosszabb anyagi helyzetú ötödben és a legjobb anyagi helyzetü ötödben a 36-42 évesek fizetik a legtöbb nettó adót, míg a 4. ötödben a 43-50 évesek, és csak a középső ötödben fizeti a legtöbb adót a 27-35 éves korosztály.

3. A legrosszabb anyagi helyzetben lévők nettó pozíciója 21 és 50 éves kor között nulla körül mozog: a 21-26 és a 43-50 közötti korcsoportok épp hogy nettó haszonélvezői, a 27-35 és a 36-42 évesek épphogy nettó befizetői az intergenerációs transzferáramlásnak

4. A 60 év felettiek körében nem a legrosszabb anyagi helyzetû kvintilis tagjai fizetik a legkevesebb nettó adót, azaz, megfordítva, nem ők a legnagyobb nettó kedvezményezettek.

Ismét megjegyezzük, hogy az ábrák keresztmetszetiek, tehát a fentiekből nem lehet közvetlen életpálya-következtetéseket levonni.

\section{ANYAGI HELYZET VAGY ÉLETKOR SZERINTI KÜLÖNBSÉGEK - REGRESSZIÓS ELEMZÉS}

A továbbiakban szisztematikus elemzésnek vetjük alá a 2. szakaszban vizuálisan vizsgált eloszlásokat. Azt vizsgáljuk, hogy az egyének által kapott transzferek, a befizetett adó és a kettő különbözeteként előálló nettó kiadás szóródásában mekkora szerepet játszanak az anyagi helyzet szerinti különbségek, és mekkora szerepe van az életkornak.

\section{A modell}

A társadalmi-demográfiai ismérvek, mint például életkor, nem, etnikum stb., egyenlőtlenségekben játszott szerepének vizsgálatára a szakirodalom olyan dekompozíciós módszereket javasol, amelyek a teljes egyenlőtlenséget a társadalmi csoportok közötti és csoportokon belüli különbségekre bontják fel (pl. Deutsch-Silber, 1999). Jelen esetben azonban nem egy dimenzió szerinti jövedelmi különbségek szerepét szeretnénk számszerúsíteni, hanem két, egymással korreláló ismérv, az anyagi helyzet és az életkor szerepét szeretnénk elkülöníteni. Ezért a kvantitatív elemzést többváltozós regressziós elemzés kereteibe helyezzük, hasonlóan pl. Cowell és Fiorio (2011) elemzéséhez. 
Az alábbi OLS regressziós modell képezi az elemzés alapját:

$$
Y=\alpha+\sum_{i} \beta_{A i} \text { Kor }_{i}+\sum_{j} \beta_{S j} \text { Státusz }_{j}+\varepsilon,
$$

ahol $Y$ az elemzés függő változóját (jóléti kiadások, bevételek vagy nettó kiadások) jelenti, Kor és Státusz $z_{j}$ az életkor és az anyagi helyzet változók kategóriái $(i, j=2, \ldots, 10), \alpha$ konstans, a $\beta$-k regressziós együtthatók, $\varepsilon$ pedig a hibatag.

A regressziós modell becslésénél mind az életkort, mind az anyagi helyzetet ordinális változóként vonjuk be a modellbe, annak érdekében, hogy a változók nem lineáris hatása kellőképpen érvényesülhessen. Mivel eljárásunk a kialakítandó csoportok közötti szóródás kiszámítására épül, az eredményt befolyásolja a kategóriák kialakítása. Ha az egyik tengely mentén elnagyoltabb osztályozást alkalmazunk, mint a másik mentén, akkor az előbbi esetben a megfigyelések közötti szóródás nagyobb részét tartjuk csoporton belül, befolyásolva ezzel a csoportok közötti szóródás mértékét. Jelen esetben mind az életkor, mind pedig az anyagi helyzet szerinti eloszlást 10 egyenlő nagyságú csoportra (tizedre) bontjuk (lásd a Függelék F2. táblázatát).

A legegyszerübb modellben csak életkorral és jövedelemmel magyarázunk - nem kívánjuk e változók hatását más kontrollokkal csökkenteni. Az elemzés célja az, hogy összehasonlítsuk az életkor szerinti és a jövedelem szerinti újraelosztás relatív fontosságát, ez pedig nem igényli, hogy a teljes szóródást minél jobban magyarázó (minél magasabb $R^{2}$-tel rendelkező) modellt keressünk. Az eredmények robusztusságának ellenőrzésére a becsléseket megismételjük olyan kontrollváltozók bevonásával is, amelyek kevésbé korrelálnak az életkorral vagy az anyagi helyzettel, mint pl. a nem, a régió és a településtípus.

Egy adott magyarázó tényező fontosságának vizsgálatánál a szakirodalom megkülönbözteti egy magyarázó változó "oksági” fontosságát és „„szóródási” fontosságát (lásd Achen, 1982). Az előbbi azt tükrözi, hogy a magyarázó változó egységnyi változása mekkora változást hoz létre a függő változóban ceteris paribus, és a regressziós együtthatóval mérhető. A "szóródási fontosság” értelmezés szerint egy magyarázó változó fontosságát az méri, hogy a függő változó szóródásának mekkora részét magyarázza. Ezt sok esetben azzal mérik, hogy mennyivel növekszik meg a regressziós modell által magyarázott szóródás $\left(R^{2}\right)$, amennyiben az adott változót bevonjuk a modellbe. Jelen esetben az ún. Shapley-érték módszert (Israeli, 2007) alkalmazzuk, amely figyelembe veszi, hogy az $R^{2}$-növekedés mértéke függ attól, hogy milyen sorrendben vonjuk be a magyarázó változókat. A Shapley-érték az összes lehetséges sorrend esetén mért $R^{2}$-növekedés átlaga; a módszer ezt az értéket tekinti egy adott változó által magyarázott résznek.

A kapott eredmények megerősítik a 2. szakaszban bemutatott ábrák alapján sejtetteket. A jóléti rendszerben az életkor mind a hozzáférés, mind a hozzájárulás területén sokkal fontosabb szempont, mint az anyagi helyzet. 
Regressziós együtthatók

A magyarázó változók fontosságának első értelmezése szerint egy változó akkor fontosabb, ha (szórás)egységnyi változása nagyobb változást indukál a függő változó értékében, tehát ha a (sztenderdizált) regressziós együtthatója nagyobb, mint egy másik változóé. Mivel jelen esetben mind az anyagi helyzet, mind az életkor változóját kategóriákra bontva vontuk be a modellbe, a regressziós együtthatók összehasonlításának megkönnyítésére három összegző mérőszámot számoltunk ki: a regressziós együtthatók abszolút értékének összegét, a legnagyobb és a legkisebb regressziós együttható különbségét, valamint az együtthatók szórását. Mindhárom mutató esetében a nagyobb érték azt mutatja, hogy összességében nagyobbak az eltérések a referencia-kategóriától. A számítások eredményeit az 1. táblázat foglalja össze.

A kiadásoknál mindhárom mutató alapján azt látjuk, hogy az életkor esetében nagyobbak a regressziós együtthatók, tehát nagyobb az eltérés a referencia-kategóriától. A bevételeknél valamelyest kiegyenlítettebb a kép, különösen, ha a legnagyobb és legkisebb regressziós együttható különbségét vagy a szórást nézzük. Ugyanakkor itt is az életkor mutatkozik fontosabbnak, bármelyik mérőszámot is nézzük. A nettó kiadások esetében is az életkor ad nagyobb értékeket. Eredményeink szerint tehát az életkor változásának nagyobb hatása van a jóléti kiadásokra és bevételekre, mint az anyagi helyzetnek. Hasonló eredményeket kapunk akkor, ha a regressziós modellekbe bevonjuk kontrollváltozóként a nem-, régió- és településtípus változókat (lásd a 3-as számú modelleket a Függelék F3-F5. táblázatában).

1. táblázat. Az anyagi helyzet és az életkor hatása a jóléti kiadásokra, bevételekre és nettó kiadásokra (sztenderdizált regressziós együtthatók összefoglaló mérőszámai)

\begin{tabular}{lcc}
\hline & Anyagi helyzet & Életkor \\
\hline Kiadások & & \\
\hline Abszolút értékek összege & 0,56 & 1,46 \\
Maximum-minimum & 0,08 & 0,48 \\
Szórás & 0,02 & 0,18 \\
Bevételek & & \\
\hline Abszolút értékek összege & 1,22 & 2,03 \\
Maximum-minimum & 0,32 & 0,38 \\
Szórás & 0,10 & 0,15 \\
Nettó kiadások & & \\
\hline Abszolút értékek összege & 1,11 & 1,67 \\
Maximum-minimum & 0,25 & 0,45 \\
Szórás & 0,08 & 0,18 \\
\hline
\end{tabular}

Forrás: A szerzók számítása

Megjegyzés: A táblázat értékeit az anyagi helyzet és az életkor sztenderdizált regressziós együtthatói alapján számoltuk ki a kontrollváltozók nélküli modellekból (lásd a Függelék F3-F5. táblázatainak Modell 2 becsléseit). 
Megmagyarázott szóródás

A magyarázó változók fontosságának másik értelmezése szerint egy változó annál fontosabb, minél nagyobb részt magyaráz a függő változó szóródásából. A 2. táblázatban foglaltuk össze az életkor és az anyagi helyzet szóródási fontosságával kapcsolatos számításaink eredményeit. A kiadások esetében a két változó összesen a függő változó szóródásának 34\%-át magyarázza $\left(R^{2}=0.343\right)$. Ez azonban csaknem kizárólag az életkor változónak köszönhető, az anyagi helyzet szerinti különbségek a kiadások szóródásának csupán 1\%-át magyarázzák, ami a modell által magyarázott szóródásnak is mindössze 3\%-a. Amenynyiben figyelembe vesszük a két változó közötti interakciót, tehát hogy az anyagi helyzet hatása különbözhet korcsoportonként, akkor az anyagi helyzet szerepe valamivel nagyobb (a modell által megmagyarázott szóródás 7\%-a), de összességében ekkor is a korcsoportok közötti eltérések teszik ki a megmagyarázott szóródás döntő hányadát (93\%-át).

2. táblázat. Az életkor és az anyagi helyzet szerepe a kiadások és bevételek szóródásában (A regressziós modell $R^{2}$-ének felbontása Shapley-érték módszerrel)

\begin{tabular}{|c|c|c|c|c|c|c|}
\hline & \multicolumn{2}{|c|}{ Kiadások } & \multicolumn{2}{|c|}{ Bevételek } & \multicolumn{2}{|c|}{ Nettó kiadások } \\
\hline & $\begin{array}{l}\text { Teljes } \\
\text { szóródás } \\
\text { \%-ában }\end{array}$ & $\begin{array}{c}\text { Magyarázott } \\
\text { szóródás } \\
\text { \%-ában }\end{array}$ & $\begin{array}{l}\text { Teljes } \\
\text { szóródás } \\
\text { \%-ában }\end{array}$ & $\begin{array}{l}\text { Magyarázott } \\
\text { szóródás } \\
\text { \%-ában }\end{array}$ & $\begin{array}{l}\text { Teljes } \\
\text { szóródás } \\
\text { \%-ában }\end{array}$ & $\begin{array}{c}\text { Magyarázott } \\
\text { szóródás } \\
\text { \%-ában }\end{array}$ \\
\hline \multicolumn{7}{|c|}{ Interakció nélkül } \\
\hline Anyagi helyzet & 1 & 3 & 12 & 33 & 8 & 19 \\
\hline Életkor & 33 & 97 & 24 & 67 & 33 & 81 \\
\hline Összesen & 34 & 100 & 36 & 100 & 41 & 100 \\
\hline \multicolumn{7}{|c|}{ Interakcióval } \\
\hline Anyagi helyzet & 3 & 7 & 15 & 36 & 11 & 23 \\
\hline Életkor & 35 & 93 & 27 & 65 & 36 & 77 \\
\hline Összesen & 37 & 100 & 42 & 100 & 47 & 100 \\
\hline
\end{tabular}

Forrás: A szerzók számítása.

Megjegyzés: Kiadás: juttatások és támogatások; bevétel: adók és járulékok; nettó kiadás: a kettő különbsége. Az interakció nélküli modellekben csak az életkor és az anyagi helyzet a magyarázó változók, az interakciós modellben ezek interakciója is szerepel.

A bevételeknél az anyagi helyzet nagyobb szerepet játszik, mint a kiadásoknál: a regressziós modell által magyarázott szóródás mintegy harmada tulajdonítható ennek a változónak. Az életkor azonban itt is egyértelmúen fontosabb magyarázó változó azzal, hogy az összes szóródás 24\%-át, a modell által magyarázott szóródás kétharmadát magyarázza. Az életkor és az anyagi helyzet interakciójának figyelembevétele nem módosítja lényegesen ezeket az eredményeket. Ha a nettó kiadásokat nézzük, akkor is egyértelmúen az életkor 
fontosabb: a magyarázott szóródás megoszlása 19\% (anyagi helyzet) a 81\%-kal (életkor) szemben. Ezen az interakció figyelembevétele sem változtat sokat: a nettó kiadások szóródásának magyarázatában az életkornak sokkal nagyobb szerepe van (77\%), mint az anyagi helyzetnek (23\%).

\section{KÖVETKEZTETÉSEK}

A fentiekben megerősítettük azt, a hazai szakmai közvéleményben már többször igazolt sejtést, hogy a jóléti programok csak kismértékben veszik figyelembe az anyagi helyzet különbségeit. Szegények és jómódúak többé-kevésbé egyformán jutnak hozzá a jóléti állam forrásaihoz. Ezt az állítást azonban kiegészítettük annak igazolásával, hogy az életkornak viszont jelentős szerepe van mind a hozzáférés, mind a finanszírozás magyarázatában. Eredményeinkből arra következtetünk, hogy a jóléti állam pontosabban leírható korosztályok közötti erőforrás-áramlás révén megvalósuló életpálya-finanszírozásként, mint szegénységenyhítésként vagy jövedelemkiegyenlítésként. ${ }^{7}$

Az általunk találtak nem normatív természetúek, és nem következik belőlük a szegénységenyhítés, jövedelemkiegyenlítés vagy általánosabban az állami beavatkozás kritikája. A jóléti rendszer politikai gazdaságtanának fősodra a rendszer létét, formáit és reformjait ideológiai fogalmak segítségével próbálja meg leírni. Esping-Andersen (1990) megkerülhetetlen osztályozása szociáldemokrata, liberális és konzervatív jóléti rendszereket különböztet meg - bár e tipológia gyorsan területivé vált, és manapság már inkább skandináv, kontinentális, angolszász és kiegészítésképp mediterrán típusokról van szó. A reformviták is többnyire a szociáldemokrata, etatista, konzervatív vagy neoliberális programok ütközeteinek tûnnek. E háttér előtt az itt használt „állami beavatkozás" kifejezés egyes olvasók szemében kritikai élt kaphat. Bár meggyőződésünk szerint sem az eddig elmondottakból, sem a továbbiakból nem következik a szerzők kritikája a jóléti állam létezésével vagy méretével szemben, fontosnak érezzük leszögezni, hogy ilyesmiről valóban szó sincs. Az életpálya-finanszírozás sokcsatornás rendszer, melynek társadalmi berendezkedéstôl függően az állam lehet marginális és lehet meghatározó szereplője egyaránt. Az életpálya-finanszírozási jelleg bemutatásából nem következik a jóléti állam leépítése, a róla szóló tudás átstrukturálása viszont igen.

Miként a bevezetésben már utaltunk rá, a jóléti rendszer életpálya-finanszírozási megközelítése új kérdéseket vet fel, más kérdéseket pedig új perspektívába helyez. Ha a jóléti állam a jómódúaktól ad át erőforrásokat a szegényeknek, akkor ezt jórészt egyedül teszi, a jövedelmek piaci allokációjának korrekciójaként. Hasonló tevékenységet legfeljebb a jótékonysági szervezetek végeznek, Magyarországon nagyságrendekkel kisebb mértékben, mint az állam. Amennyiben a jóléti rendszer elsősorban életpályát finanszíroz korcso- 
portok közötti erőforrás-átadás révén, figyelembe kell vennünk, hogy az állam az életpálya-finanszírozásnak nem egyedüli, sőt a legtöbb országban nem is a legfontosabb intézménye. Az aktív korúaktól a gyermekekhez és idősekhez kerülő pénz- és munkatranszferek számottevő része nem járja meg a jóléti rendszert, hanem közvetlenül családtagok között cserél gazdát, vagy piaci intézmények közvetítésével jut el a donortól a kedvezményezetthez.

A közkiadások politikai gazdaságtana szempontjából ez azért releváns, mert az életpálya-finanszírozási rendszer intézményei között munkamegosztás van: az aktív korúak elsősorban állami csatornákon keresztül támogatják az időseket, és főként családon belül, magántranszferek révén a gyermekeket. Ezt a megfigyelést igazolja Gál, Vanhuysse és Vargha (2018), akik tíz európai ország adatain, melyek az EU népességének 70\%-át képviselik és lefedik valamennyi jólétirezsim-típust, bemutatja, hogy az idős európai átlagember két és félszer annyi közkiadáshoz jut, mint egy átlaggyermek: a 30-49 évesek átlagos munkajövedelmében mérve 37\%-hoz a 15\%-kal szemben. ${ }^{8}$ Ez a megfigyelés egybeesik az „idősuralom” és az „idősekhez húzás” szakirodalmának megállapításaival. Az idézett tanulmány azonban azt is bemutatja, hogy ha a háztartáson belül együtt élő generációk között gazdát cserélő erőforrásokat is figyelembe vesszük, a kép radikálisan megváltozik. A tipikus európai háztartásszerkezetben elsősorban arról van szó, hogy a szülők eltartják kiskorú gyermekeiket. Az egy gyermekhez jutó együttes közösségi-magán transzfercsomag már valamivel nagyobb (az említett munkajövedelem-skálán kifejezve $39 \%)$, mint amit egy idős kap (34\%, kevesebb mint a közösségi transzferek, mivel ebből az idősek nettóban valamennyit átadnak a náluk fiatalabbaknak). Ha pedig ehhez hozzáadjuk a nem fizetett háztartási munka értékét, azt, hogy a szülő́k nem csupán kifizetik gyermekeik fogyasztását, hanem dolgoznak is rájuk, az eredeti arányok nem egyszerúen kiegyenlítődnek, hanem megfordulnak: a teljes transzfercsomagból, amely a közösségi, a magán és a munkatranszfereket is tartalmazza, az európai átlaggyermek csaknem két és félszer annyit kap, mint az átlag idős (a 30-49 évesek egy főre eső munkajövedelmének 73\%-át az idősek 31\%-ával szemben).

E számok sokkal inkább az életpálya-finanszírozó intézmények közötti munkamegosztásról árulkodnak, mint arról, hogy az idősek kisajátítanák az erőforrásokat. Azt pedig, hogy a keresztmetszetben megfigyelt megoszlásokat előállító történeti folyamat valóban az idősek dominanciájának erősödése lett volna, vagy valami más, még ebből a pillanatfelvételből sem tudjuk meg. Vajon a gyermekek egyelöre még többe kerülnek, ${ }^{9}$ mint az idősek, vagy mostanra már többe kerülnek? Vajon az idősek időben növekvő közösségi transzferei megnövelték a teljes, hozzájuk jutó transzfercsomagot? Vagy ez csupán kompenzáció volt a csökkenő magántranszferekért és munkatranszferekért, amik elsősorban azért estek vissza, mert az idősek egyre ritkábban élnek együtt felnőtt gyermekeikkel? Bár egyelőre nem tudjuk megválaszolni ezeket a 
kérdéseket, azt a fentiek fényében mindenképpen meg tudjuk állapítani, hogy az idősek részesedésének megfigyelt növekedése nem csupán a kiszorítási történettel konzisztens. A folyamat minden további nélkül végbemehetett úgy is, hogy a gyermekeknek jutó transzfercsomag értéke ugyanúgy nőtt, mint az időseké. A folyamat, amit „lopakodó gerontokráciának” érzékelünk, végbemehetett úgy is, hogy közben a 20. század a "gyermekek évszázadává" vált (miként azt Key [1909] a század elején jövendölte): a termelékenység gyors növekedését a nyugati társadalmak arra fordították, hogy az inaktív életszakaszukban járók életkörülményeit az átlagnál gyorsabban javítsák.

Bár tanulmányunkban csak magyar adatokat elemeztünk, a felvetett kérdések természetesen nemcsak hazánkra vonatkoznak. Kohli (2015) véleménye szerint a fejlett országok népességének idősödése és ennek a jóléti újraelosztás fenntarthatóságára gyakorolt hatása miatt a korosztályok közötti politikai törésvonalak erősödhetnek a jövőben. Ez tükröződhet az egyes nemzedékek növekvő politikai aktivitásában, és a pártok kommunikációjában, közpolitikai ígéreteiben is erősödhetnek a korosztályi üzenetek. Ugyanakkor Kohli (2015) sem számít a generációs konfliktus kiéleződésére, a nemzedékek „háborújára”. Véleménye szerint a családi szolidaritás és az egyéb intézményes (pl. politikai szervezeteken keresztüli) integrációs mechanizmusok elég erősek ahhoz, hogy ezt megakadályozzák.

\section{JEGYZETEK}

1 A tanulmány a K112900 sz. OTKA-kutatás támogatásával készült. Köszönetet mondunk a kutatás résztvevőinek, továbbá Kézdi Gábornak, Saumik Paulnak és Pieter Vanhuyssénak a korábbi változathoz fúzött megjegyzéseikért. Az esetleg megmaradt hibákért természetesen ők nem felelősek.

2 E tanulmányban a ,jóléti állam”, ,jóléti rendszer", „,szociálpolitika” kifejezéseket szinonimákként kezeljük. A jóléti állam határai nem egyértelmúek; feladataival kapcsolatban a szakirodalom többnyire tartózkodik a pontos meghatározástól. E helyütt szintén egy szándékoltan elnagyolt körülírással élünk: a szociálpolitika állami beavatkozás az állampolgárok jólétének növelése érdekében. A jóléti rendszer részeinek egyes nemzetközi szervezetek, mint az OECD, az IMF, az Eurostat, vagy fontosabb felsőoktatási programok és tankönyvek, mint a London School of Economics szociálpolitikai tanszékének vagy a Malcolm Wiener Center for Social Policy at Harvard University kurrikuluma, illetve Barr, 1987 alapján a közoktatást, közegészségügyet, illetve a különféle önkormányzati, társadalombiztosítási vagy központi kormányzati finanszírozású készpénzes szociális programokat tekintjük.

3 Ami az állam számára bevétel, az a polgára számára kiadás, és fordítva. A ma általános megközelítés az állam szemszögéből vizsgálja a jóléti célú beavatkozás folyamatait. Az itt alkalmazott megközelítéssel inkább a fordított szóhasználat csengene egybe. Ha a jóléti rendszerben az életciklusuk különböző pontján járó emberek szervezik meg a közöttük zajló jövedelem- 
áramlást, aminek az állam csak egyik csatornája, akkor az adó kiadás, a juttatás vagy támogatás pedig bevétel. A gördülékenyebb fogalmazás érdekében azonban maradunk az elterjedt, állam-nézőpontú szóhasználatnál.

4 A gyermekszám szerint kapott személyijövedelemadó-kedvezmény is tekinthető önálló készpénzes programnak. Általában véve az adókedvezmény formájában adott támogatás a gazdagabbak számára kedvező. A szóban forgó adókedvezmény azonban nem pusztán az anyagi helyzethez kötődik, hanem az életkorhoz is. Az alkalmazott adóincidencia-feltevéstől függően (nevezetesen, hogy a családtámogatásokat a gyermeknél vagy a szülőnél írjuk-e jóvá; erről lásd a főszöveget) a kérdéses kedvezmény vagy a gyermekeknél köt ki (de nem az aktív korúaknál vagy az időseknél), vagy olyan, jellemzően a 30-as vagy 40-es éveikben járó aktív korúak kapják - de nem a gyermekek, a fiatalabb vagy idősebb aktív korúak és nem az idősek -, akiknek még több eltartott gyermekük van.

5 Incidenciaválasztásunk során eltértünk a szokásostól. A tipikus incidenciakérdés így hangzik: ki fizeti valójában az adókat? A válasz pedig az eladók és vevők jövedelemrugalmasságától függ (Pechman, 1985; Fullerton-Metcalf, 2002). Adók helyett transzferekre kivetítve, ez a megoldás azt vizsgálja, hogy a beavatkozás miként változtatja meg az érintettek fogyasztását. A kérdés feltevése ebben a formában azonban már feltételezi a kérdéses adók vagy transzferek létezését, ami adók esetén indokolt, transzferek esetén azonban nem. Az itt alkalmazott megközelítés ehelyett a transzfer létezését célozza: kapna-e egy család családtámogatást gyermek nélkül. Egyértelmú ugyanis, hogy aszimmetria mutatkozik az adók és transzferek incidenciavizsgálatában, adók ugyanis mindenképpen vannak, transzferek viszont nem feltétlenül.

6 Az egyéni benzinfogyasztást a háztartási értékekből a Baranyai-féle kulcs segítségével számítottuk (Gál et al., (2004).

7 Az az elképzelés, mely szerint a jóléti állam nem más, mint életpálya-finanszírozás együtt élő korosztályok közötti erőforrás-átadás révén, több változatban is régóta jelen van a szakirodalomban. Helyszúke miatt itt nem tudjuk áttekinteni a vonatkozó hivatkozásokat. Részletekért lásd Gál és Medgyesi (2017) írását.

8 A hivatkozott tanulmány a Nemzeti Transzferszámlák (az angol név rövidítésével NTA; lásd Lee-Mason, 2011) projekt keretében készült. Az NTA az egy főre eső értékeket, így az adóbefizetések, járulékok, támogatások, juttatások egy főre eső értékét a 30-49 évesek egy főre jutó munkajövedelmében méri annak érdekében, hogy az országok közötti összehasonlítást ne befolyásolja az átváltási árfolyam vagy a vásárlóerő-paritás torzító hatása.

9 Az a megállapítás, hogy a gyermekek „többe kerülnek”, azt jelenti, hogy több transzfert kapnak, nem azt, hogy többet költenek. Az idősek egy főre esően többet fogyasztanak, ennek számottevő részét azonban nem transzferek, hanem saját munkajövedelmük, illetve a tulajdonukból származó jövedelem (Magyarországon elsősorban a lakástulajdonlásból fakadó beszámított lakbér) fedezi. 


\section{IRODALOM}

Achen, C. H. (1982): Interpreting and using regression. (Quantitative Applications in the Social Sciences, 29.) Beverly Hills, CA: Sage Publications. http://dx.doi.org/10.4135/9781412984560

Barr, N. (1987): Economics of the welfare state. Oxford: Oxford University Press.

Bartha A. - Tóth A. (2013): A magyar nyugdíjrendszer változásai politikatudományi perspektívából. Politikatudományi Szemle, 23 (4), 161-183.

Becker, G. - Murphy, K. (1988): The family and the state. Journal of Law and Economics 31(1), 1-18. https://doi.org/10.1086/467147

Benedek, D. - Firle, R. - Scharle, Á. (2006): The efficiency of welfare redistribution (in Hungarian). (Közpénzügyi Füzetek, 17.) Budapest.

Boldrin, M. és Montes, A. (2005): The Intergenerational State Education and Pensions. Review of Economic Studies, 72, 651-664. https://doi.org/10.1111/j.1467-937X.2005.00346.x

Cowell, F. A. - Fiorio, C. V. (2011): Inequality decompositions - a reconciliation. Journal of Economic Inequality, 9 (4), 509-528. https://doi.org/10.1007/s10888-011-9176-1

Deutsch, J. - Silber, J. (1999): Inequality Decomposition by Population Subgroups and the Analysis of Interdistributional Inequality. In: J. Silber (szerk.): Handbook of Income Inequality Measurement. /Recent Economic Thought Series, 71./ Dordrecht: Springer. 363-403. https://doi. org/10.1007/978-94-011-4413-1_14

Esping-Andersen, G. (1990): The three worlds of welfare capitalism. Princeton: Princeton University Press.

Ferge, Z. (2000): Inequalities unchained - State, governments, civil organisations (in Hungarian). Budapest: Hilscher Rezső Szociálpoltikai Egyesület.

Ferge, Z. - Tausz, K. (2002): Social security in Hungary : A balance sheet after twelve years. Social Policy and Administration, 36 (2), 176-199. https://doi.org/10.1111/1467-9515.00278

Folbre, N. - Wolf, D. (2012): The Intergenerational Welfare State. Population and Development Review, 38 (Supplement), 36-51. https://doi.org/10.1111/j.1728-4457.2013.00550.x

Fullerton, D. - Metcalf, G. E. (2002): Tax incidence. In: A. Auerbach - M. Feldstein (eds.): Handbook of Public Economics, Vol. 4. Amsterdam: Elsevier. 1787-1872. https://doi.org/10.1016/S15734420(02)80005-2

Gál, R. I. - Medgyesi, M. (2017): Financing the lifecycle or mitigating poverty: Redistribution in the Hungarian welfare system by age and income. (NTA Working Papers, No. 17/5.) Berkeley-Honolulu. http://www.ntaccounts.org/doc/repository/GM 2017.pdf

Gál R. I. - Medgyesi M. - Révész T. - Törzsök Á. (2004): Az államháztartási mérleg lebontása korcsoportos nettó adóprofilokra, 1992-2002. Budapest.

Gál, R. I. - Vanhuysse, P. - Vargha, L. (2018): Pro-elderly welfare states within pro-child societies. Journal of European Public Policy, 25 (6), 944-958. https://doi.org/10.1080/13501763.2017.140 1112

Ganzeboom, H. B. G. - Treiman, D. J. (2010): International Stratification and Mobility File: Conversion Tools. http://www.harryganzeboom.nl/ismf/index.htm

Guio, A.-C. (2009): What can be learned from material deprivation indicators in Belguim and in its regions? (Eurostat Methodologies and Working Papers). Luxembourg. 
Israeli, O. (2007): A Shapley-Based Decomposition of the R -Square of a Linear Regression. Journal of Economic Inequality, 5 (2), 199-212. https://doi.org/10.1007/s10888-006-9036-6

Key, E. K. S. (1909): The Century of the Child. New York: Putnam.

Kohli, M. (2015): Generations in Aging Societies: Inequalities, Cleavages, Conflicts. In: Cornelius Torp (eds.): Challenges of Aging. Pensions, Retirement and Generational Justice. Palgrave Macmillan, 265-288. https://doi.org/10.1057/9781137283177_14

Kotlikoff, L. J. - Burns, S. (2012): The Clash of Generations. Cambridge MA: MIT.

Lee, R. D. - Mason, A. (eds.) (2011): Population Aging and the Generational Economy. Cheltenham UK - Northampton MA: Edward Elgar. https://doi.org/10.4337/9780857930583

Lynch, J. (2006): Age in the Welfare State. Cambridge UK: Cambridge University Press. https://doi.org/10.1017/CBO9780511606922

Pechman, J. A. (1985): Who Paid the Taxes, 1966-85? Washington DC: Brookings Institution Press.

Preston, S. H. (1984): Children and the elderly: Divergent paths for America's dependents. Demography, 21 (4), 435-457. https://doi.org/10.2307/2060909Révész, T. (2002): Social stratification of household income and taxes (in Hungarian). Statisztikai Szemle, 80, 371-393.

Sinn, H.-W. - Uebelmesser, S. (2003): Pensions and the path to gerontocracy in Germany. European Journal of Political Economy, 19 (1), 153-158. https://doi.org/10.1016/S0176-2680(02)001349

Szabó A. - Kiss B. (2013): Konfliktus és generáció. A generációs konfliktusok kutatásának fogalmi kiindulópontjai. Politikatudományi Szemle, 23 (4), 97-115.

Szikra, D. (2014): Democracy and welfare in hard times: The social policy of the Orbán Government in Hungary between 2010 and 2014. Journal of European Social Policy, 24 (5), 486-500. https://doi.org/10.1177/0958928714545446

Tepe, M. S. - Vanhuysse, P. (2010): Elderly bias, new social risks, and social spending: Change and timing in eight programs across four worlds of welfare, 1980-2003. Journal of European Social Policy, 20 (3), 218-234. https://doi.org/10.1177/0958928710364436

van Groezen, B. - Leers, Th. - Meijdam, L. (2003): Social security and endogenous fertility. Pensions and child allowances as Siamese twins. Journal of Public Economics, 87 (2), 233-251. https:// doi.org/10.1016/S0047-2727(01)00134-7

Vanhuysse, P. (2013): Intergenerational Justice in Aging Societies. Gütersloh: Bertelsmann Stiftung.

Verbist, G. - Förster, M. F. - Vaalavuo, M. (2012): The impact of publicly provided services on the distribution of resources: Review of new results and methods. (OECD Social, Employment and Migration Working Papers, No. 130.) Paris. https://doi.org/10.1787/5k9h363c5szq-en 


\section{FÜGGELÉK}

F1. táblázat. Jóléti kiadások és bevételek életkori és anyagi helyzet szerinti csoportokban 2011-ben (éves, egy fơre jutó értékek, Ft)

\begin{tabular}{|c|c|c|c|c|c|c|}
\hline & 1. kvintilis & 2. & 3. & 4. & 5. kvintilis & Összesen \\
\hline \multicolumn{7}{|c|}{ Kiadások } \\
\hline 0-10 éves & 657560 & 645818 & 693043 & 723727 & 744453 & 691010 \\
\hline $11-20$ & 799733 & 814174 & 855224 & 828809 & 836016 & 824588 \\
\hline $21-26$ & 390449 & 329252 & 341521 & 376454 & 375305 & 363253 \\
\hline $27-35$ & 419648 & 222134 & 121127 & 185338 & 119811 & 197568 \\
\hline $36-42$ & 445115 & 232740 & 173047 & 153517 & 118410 & 216493 \\
\hline $43-50$ & 636502 & 374743 & 268195 & 262129 & 181088 & 339317 \\
\hline $51-56$ & 923253 & 704117 & 466048 & 455439 & 399858 & 576103 \\
\hline $57-61$ & 1322867 & 1147744 & 1155945 & 1040704 & 818975 & 1090515 \\
\hline $62-71$ & 1183351 & 1219749 & 1372459 & 1384804 & 1584541 & 1343307 \\
\hline $72+$ éves & 1323629 & 1354803 & 1397154 & 1535104 & 1598444 & 1423966 \\
\hline \multicolumn{7}{|c|}{ Bevételek } \\
\hline & 1. kvintilis & 2. & 3. & 4. & 5. kvintilis & Összesen \\
\hline 0-10 éves & 47002 & 69149 & 87282 & 100467 & 130702 & 85255 \\
\hline $11-20$ & 89321 & 154126 & 159045 & 208269 & 225923 & 160124 \\
\hline $21-26$ & 349290 & 556613 & 646696 & 705418 & 871552 & 639912 \\
\hline $27-35$ & 477479 & 807654 & 1075741 & 1300776 & 1938563 & 1207338 \\
\hline $36-42$ & 507877 & 863385 & 1118323 & 1351318 & 1987438 & 1191332 \\
\hline $43-50$ & 574712 & 925109 & 1146566 & 1479460 & 1915227 & 1208748 \\
\hline $51-56$ & 549621 & 831336 & 1087474 & 1483073 & 1908631 & 1203642 \\
\hline $57-61$ & 402089 & 526586 & 749971 & 987168 & 1606100 & 863917 \\
\hline $62-71$ & 190986 & 236377 & 294791 & 319179 & 667059 & 333544 \\
\hline 72 + éves & 180047 & 184926 & 211447 & 235481 & 334338 & 220932 \\
\hline \multicolumn{7}{|c|}{ Nettó kiadások } \\
\hline & 1. kvintilis & 2. & 3. & 4. & 5. kvintilis & Összesen \\
\hline 0-10 éves & 610558 & 576669 & 605760 & 623260 & 613751 & 605754 \\
\hline $11-20$ & 710412 & 660048 & 696180 & 620540 & 610093 & 664464 \\
\hline $21-26$ & 41159 & -227361 & -305175 & -328964 & -496247 & -276659 \\
\hline $27-35$ & -57832 & -585520 & -954615 & -1115438 & -1818752 & -1009770 \\
\hline $36-42$ & -62762 & -630644 & -945276 & -1197801 & -1869028 & -974839 \\
\hline $43-50$ & 61790 & -550367 & -878371 & -1217331 & -1734139 & -869432 \\
\hline $51-60$ & 373632 & -127218 & -621426 & -1027635 & -1508774 & -627539 \\
\hline $57-61$ & 920779 & 621158 & 405974 & 53536 & -787125 & 226598 \\
\hline $62-71$ & 992364 & 983372 & 1077668 & 1065625 & 917482 & 1009763 \\
\hline 72+ éves & 1143583 & 1169877 & 1185706 & 1299623 & 1264106 & 1203035 \\
\hline
\end{tabular}




\section{GÁL RÓBERT IVÁN - MEDGYESI MÁRTON}

F2. táblázat. Az elemzésben használt életkori és anyagi helyzet szerinti csoportosítás

\begin{tabular}{|c|c|c|c|c|}
\hline \multicolumn{5}{|c|}{ Életkori csoportok } \\
\hline & $\begin{array}{l}\text { Minimum } \\
\text { (év) }\end{array}$ & $\begin{array}{l}\text { Maximum } \\
\text { (év) }\end{array}$ & $\begin{array}{l}\text { Átlag } \\
\text { (év) }\end{array}$ & $\begin{array}{c}\text { Arány a teljes } \\
\text { népességben (\%) }\end{array}$ \\
\hline 1 & 0 & 10 & 5,0 & 10,9 \\
\hline 2 & 11 & 20 & 15,9 & 10,3 \\
\hline 3 & 21 & 26 & 23,3 & 8,8 \\
\hline 4 & 27 & 35 & 31,3 & 10,7 \\
\hline 5 & 36 & 42 & 38,9 & 9,6 \\
\hline 6 & 43 & 50 & 46,5 & 10,8 \\
\hline 7 & 51 & 56 & 53,7 & 9,8 \\
\hline 8 & 57 & 61 & 58,9 & 9,4 \\
\hline 9 & 62 & 71 & 66,0 & 10,5 \\
\hline 10 & 72 & 100 & 78,6 & 9,2 \\
\hline \multicolumn{5}{|c|}{ Anyagi helyzet (státus score-ok) alapján képzett csoportok } \\
\hline & Minimum & Maximum & Átlag & $\begin{array}{c}\text { Aránya a teljes } \\
\text { népességben (\%) }\end{array}$ \\
\hline 1 & $-4,0$ & $-1,6$ & $-2,2$ & 10,0 \\
\hline 2 & $-1,6$ & $-1,0$ & $-1,3$ & 9,8 \\
\hline 3 & $-1,0$ & $-0,7$ & $-0,8$ & 10,0 \\
\hline 4 & $-0,7$ & $-0,3$ & $-0,5$ & 9,7 \\
\hline 5 & $-0,3$ & 0,0 & $-0,2$ & 9,9 \\
\hline 6 & 0,0 & 0,4 & 0,2 & 9,8 \\
\hline 7 & 0,5 & 0,9 & 0,7 & 9,9 \\
\hline 8 & 0,9 & 1,6 & 1,3 & 9,9 \\
\hline 9 & 1,6 & 2,3 & 2,0 & 9,8 \\
\hline 10 & 2,3 & 3,5 & 2,7 & 9,8 \\
\hline
\end{tabular}




\section{JÓLÉTI ÁLLAM: KORCSOPORTOK KÖZÖTTI ÚJRAELOSZTÁS?}

F3. táblázat. Sztenderdizált regressziós együtthatók a jóléti kiadásokat magyarázó regressziós modellben

\begin{tabular}{|c|c|c|c|c|c|c|}
\hline Anyagi helyzet & \multicolumn{2}{|c|}{ Model 1} & \multicolumn{2}{|c|}{ Model 2} & \multicolumn{2}{|c|}{ Model3 } \\
\hline 1. tized & 0,000 & () & 0,000 & () & 0.000 & () \\
\hline 2. tized & $-0,039^{* * *}$ & $(-4,49)$ & $-0,027^{* * *}$ & $(-3,79)$ & $-0,025^{* * *}$ & $(-3,60)$ \\
\hline 3. tized & $-0,079^{* * *}$ & $(-9,21)$ & $-0,058^{* * *}$ & $(-8,28)$ & $-0,056^{* * *}$ & $(-7,92)$ \\
\hline 4. tized & $-0,083^{* * *}$ & $(-9,70)$ & $-0,060^{* * * *}$ & $(-8,55)$ & $-0,057^{* * *}$ & $(-8,07)$ \\
\hline 5. tized & $-0,100^{* * *}$ & $(-11,83)$ & $-0,067^{* * *}$ & $(-9,56)$ & $-0,064^{* * *}$ & $(-9,19)$ \\
\hline 6. tized & $-0,093^{* * *}$ & $(-11,01)$ & $-0,070^{* * *}$ & $(-10,00)$ & $-0,066^{* * *}$ & $(-9,46)$ \\
\hline 7. tized & $-0,084^{* * *}$ & $(-9,93)$ & $-0,063^{* * *}$ & $(-9,11)$ & $-0,061^{* * *}$ & $(-8,78)$ \\
\hline 8. tized & $-0,109^{* * *}$ & $(-13,03)$ & $-0,068^{* * *}$ & $(-9,93)$ & $-0,066^{* * *}$ & $(-9,43)$ \\
\hline 9. tized & $-0,116^{* * *}$ & $(-13,84)$ & $-0,065^{* * *}$ & $(-9,52)$ & $-0,063^{* * *}$ & $(-9,00)$ \\
\hline 10. tized & $-0,112^{* * *}$ & $(-13,57)$ & $-0,079 * * *$ & $(-11,73)$ & $-0,080^{* * *}$ & $(-11,42)$ \\
\hline Életkor & & & & & & \\
\hline 0-10 éves & & & 0,000 & () & 0,000 & () \\
\hline 11-20 éves & & & $0,077^{* * *}$ & $(10,12)$ & $0,078^{* * *}$ & $(10,20)$ \\
\hline 21-26 éves & & & $-0,113^{* * *}$ & $(-16,23)$ & $-0,112^{* * *}$ & $(-16,19)$ \\
\hline 27-35 éves & & & $-0,183^{* * *}$ & $(-25,00)$ & $-0,182^{* * *}$ & $(-24,93)$ \\
\hline 36-42 éves & & & $-0,170^{* * *}$ & $(-23,40)$ & $-0,170^{* * *}$ & $(-23,40)$ \\
\hline 43-50 éves & & & $-0,127^{* * *}$ & $(-17,09)$ & $-0,127^{* * *}$ & $(-17,00)$ \\
\hline 51-60 éves & & & $-0,011$ & $(-1,56)$ & $-0,010$ & $(-1,43)$ \\
\hline 57-61 éves & & & $0,199 * * *$ & $(27,45)$ & $0,199^{* * *}$ & $(27,55)$ \\
\hline 62-71 éves & & & $0,284^{* * *}$ & $(38,84)$ & $0,284^{* * *}$ & $(38,76)$ \\
\hline $72+$ éves & & & $0,295^{* * *}$ & $(41,07)$ & $0,297^{* * *}$ & $(41,05)$ \\
\hline Kontrollváltozó & \multicolumn{2}{|c|}{ Nincs } & \multicolumn{2}{|c|}{ Nincs } & \multicolumn{2}{|c|}{ Igen } \\
\hline $\mathrm{N}$ & \multicolumn{2}{|c|}{22249} & \multicolumn{2}{|c|}{22249} & \multicolumn{2}{|c|}{22249} \\
\hline $\mathrm{R}^{2}$ & \multicolumn{2}{|c|}{0,016} & \multicolumn{2}{|c|}{0,344} & \multicolumn{2}{|c|}{0,346} \\
\hline
\end{tabular}

Megjegyzés: $t$ statisztikák zárójelben, * $p<0,05, * * p<0,01, * * * p<0,001$. Model 3 nem, régió és településtípus kontrollokat tartalmaz. 


\section{GÁL RÓBERT IVÁN - MEDGYESI MÁRTON}

F4. táblázat. Sztenderdizált regressziós együtthatók a jóléti bevételeket magyarázó regressziós modellben

\begin{tabular}{|c|c|c|c|c|c|c|}
\hline Anyagi helyzet & \multicolumn{2}{|c|}{ Model 1} & \multicolumn{2}{|c|}{ Model 2} & \multicolumn{2}{|c|}{ Model 3} \\
\hline 1. tized & 0,000 & () & 0,000 & () & 0,000 & () \\
\hline 2 & $0,046^{* * *}$ & $(5,69)$ & $0,022^{* *}$ & $(3,19)$ & $0,016^{*}$ & $(2,31)$ \\
\hline 3 & $0,086^{* * * *}$ & $(10,69)$ & $0,050^{* * *}$ & $(7,28)$ & $0,044^{* * *}$ & $(6,38)$ \\
\hline 4 & $0,106^{* * *}$ & $(13,22)$ & $0,069^{* * *}$ & $(10,03)$ & $0,058^{* * *}$ & $(8,41)$ \\
\hline 5 & $0,132^{* * * *}$ & $(16,65)$ & $0,086^{* * * *}$ & $(12,48)$ & $0,073^{* * *}$ & $(10,77)$ \\
\hline 6 & $0,166^{* * *}$ & $(20,86)$ & $0,126^{* * *}$ & $(18,39)$ & $0,112^{* * *}$ & $(16,43)$ \\
\hline 7 & $0,191^{* * *}$ & $(24,10)$ & $0,148^{* * *}$ & $(21,65)$ & $0,132^{* * *}$ & $(19,41)$ \\
\hline 8 & $0,223^{* * * *}$ & $(28,33)$ & $0,173^{* * *}$ & $(25,51)$ & $0,154^{* * *}$ & $(22,77)$ \\
\hline 9 & $0,282^{* * * *}$ & $(35,90)$ & $0,233^{* * * *}$ & $(34,49)$ & $0,211^{* * *}$ & $(30,93)$ \\
\hline 10. tized & $0,357^{* * *}$ & $(46,07)$ & $0,317^{* * *}$ & $(47,53)$ & $0,283^{* * *}$ & $(41,56)$ \\
\hline \multicolumn{7}{|l|}{ Életkor } \\
\hline 0-10 éves & & & 0,000 & () & 0,000 & () \\
\hline $11-20$ & & & $0,043^{* * *}$ & $(5,73)$ & $0,045^{* * *}$ & $(6,02)$ \\
\hline $21-26$ & & & $0,162^{* * *}$ & $(23,62)$ & $0,163^{* * *}$ & $(24,18)$ \\
\hline $27-35$ & & & $0,356^{* * *}$ & $(49,42)$ & $0,353^{* * *}$ & $(49,68)$ \\
\hline $36-42$ & & & $0,350^{* * *}$ & $(48,90)$ & $0,351^{* * *}$ & $(49,76)$ \\
\hline $43-50$ & & & $0,382^{* * *}$ & $(52,01)$ & $0,385^{* * *}$ & $(53,20)$ \\
\hline $51-60$ & & & $0,353^{* * *}$ & $(49,19)$ & $0,359 * * *$ & $(50,72)$ \\
\hline $57-61$ & & & $0,242^{* * *}$ & $(33,85)$ & $0,243^{* * *}$ & $(34,47)$ \\
\hline $62-71$ & & & $0,080^{* * *}$ & $(11,13)$ & $0,079 * * *$ & $(11,11)$ \\
\hline $72+$ éves & & & $0,058^{* * *}$ & $(8,15)$ & $0,058^{* * *}$ & $(8,20)$ \\
\hline Kontrollváltozó & \multicolumn{2}{|c|}{ Nincs } & \multicolumn{2}{|c|}{ Nincs } & \multicolumn{2}{|c|}{ Igen } \\
\hline $\mathrm{N}$ & \multicolumn{2}{|c|}{22249} & \multicolumn{2}{|c|}{22249} & \multicolumn{2}{|c|}{22249} \\
\hline $\mathrm{R} 2$ & \multicolumn{2}{|c|}{0,134} & \multicolumn{2}{|c|}{0,363} & \multicolumn{2}{|c|}{0,382} \\
\hline
\end{tabular}

Megjegyzés: $t$ statisztikák zárójelben, ${ }^{*} p<0,05,{ }^{* *} p<0,01, * * * p<0,001$. Model 3 nem, régió és településtípus kontrollokat tartalmaz. 


\section{JÓLÉTI ÁLLAM: KORCSOPORTOK KÖZÖTTI ÚJRAELOSZTÁS?}

F5. táblázat. Sztenderdizált regressziós együtthatók a nettó jóléti kiadásokat befizetéseket magyarázó regressziós modellben

\begin{tabular}{|c|c|c|c|c|c|c|}
\hline & \multicolumn{2}{|c|}{ Model 1} & \multicolumn{2}{|c|}{ Model 2} & \multicolumn{2}{|c|}{ Model 3} \\
\hline 1. tized & 0 & () & 0 & () & 0 & () \\
\hline 2 & $-0,051^{* * *}$ & $(-6,18)$ & $-0,029^{* * *}$ & $(-4,33)$ & $-0,024^{* * *}$ & $(-3,61)$ \\
\hline 3 & $-0,099^{* * *}$ & $(-12,05)$ & $-0,065^{* * * *}$ & $(-9,67)$ & $-0,059^{* * *}$ & $(-8,84)$ \\
\hline 4 & $-0,115^{* * *}$ & $(-13,96)$ & $-0,078^{* * *}$ & $(-11,71)$ & $-0,069^{* * *}$ & $(-10,30)$ \\
\hline 5 & $-0,141^{* * *}$ & $(-17,35)$ & $-0,092^{* * *}$ & $(-13,95)$ & $-0,083^{* * *}$ & $(-12,54)$ \\
\hline 6 & $-0,160^{* * *}$ & $(-19,62)$ & $-0,121^{* * *}$ & $(-18,25)$ & $-0,110^{* * *}$ & $(-16,54)$ \\
\hline 7 & $-0,171^{* * *}$ & $(-21,11)$ & $-0,131^{* * *}$ & $(-19,99)$ & $-0,120^{* * *}$ & $(-18,18)$ \\
\hline 8 & $-0,206^{* * *}$ & $(-25,57)$ & $-0,151^{* * *}$ & $(-23,10)$ & $-0,137^{* * *}$ & $(-20,84)$ \\
\hline 9 & $-0,248^{* * *}$ & $(-30,91)$ & $-0,189^{* * *}$ & $(-29,02)$ & $-0,173^{* * *}$ & $(-26,14)$ \\
\hline 10. tized & $-0,296^{* * *}$ & $(-37,32)$ & $-0,252^{* * *}$ & $(-39,22)$ & $-0,230^{* * *}$ & $(-34,74)$ \\
\hline \multicolumn{7}{|l|}{ Életkor } \\
\hline $0-10$ éves & & & 0 & () & 0 & () \\
\hline $11-20$ & & & 0,013 & $(1,78)$ & 0,012 & $(1,69)$ \\
\hline $21-26$ & & & $-0,167^{* * *}$ & $(-25,35)$ & $-0,168^{* * *}$ & $(-25,63)$ \\
\hline $27-35$ & & & $-0,333^{* * *}$ & $(-48,00)$ & $-0,331^{* * *}$ & $(-47,93)$ \\
\hline $36-42$ & & & $-0,323^{* * *}$ & $(-46,74)$ & $-0,324^{* * *}$ & $(-47,12)$ \\
\hline $43-50$ & & & $-0,321^{* * * *}$ & $(-45,31)$ & $-0,323^{* * * *}$ & $(-45,83)$ \\
\hline $51-60$ & & & $-0,240^{* * *}$ & $(-34,61)$ & $-0,243^{* * *}$ & $(-35,30)$ \\
\hline $57-61$ & & & $-0,053^{* * *}$ & $(-7,72)$ & $-0,053^{* * *}$ & $(-7,81)$ \\
\hline $62-71$ & & & $0,099^{* * *}$ & $(14,29)$ & $0,100^{* * *}$ & $(14,44)$ \\
\hline $72+$ éves & & & $0,120^{* * *}$ & $(17,59)$ & $0,121^{* * *}$ & $(17,72)$ \\
\hline Kontrollváltozó & \multicolumn{2}{|c|}{ Nincs } & \multicolumn{2}{|c|}{ Nincs } & \multicolumn{2}{|c|}{ Igen } \\
\hline $\mathrm{N}$ & \multicolumn{2}{|c|}{22249} & \multicolumn{2}{|c|}{22249} & \multicolumn{2}{|c|}{22249} \\
\hline $\mathrm{R}^{2}$ & \multicolumn{2}{|c|}{0,092} & \multicolumn{2}{|c|}{0,407} & \multicolumn{2}{|c|}{0,416} \\
\hline
\end{tabular}

Megjegyzés: $t$ statisztikák zárójelben, * $p<0,05, * * p<0,01, * * * p<0,001$. Model 3 nem, régió és településtípus kontrollokat tartalmaz. 